\title{
Development of Innovative Designs for Ladies Kurta using Traditional Haryana Motifs
}

\author{
Sunita*, Neelam M. Rose and Saroj S. Jeet Singh \\ Department of Textile and Apparel Designing, I.C. College of Home Science, \\ CCS HAU, Hisar, India \\ *Corresponding author
}

Keywords

speed, pattern creation, editing, repeating, flexibility, variety

Article Info

\section{Accepted:}

12 March 2021

Available Online:

10 April 2021
The rich motifs and designs of the traditional arts and crafts can be readily adapted into contemporary forms in an attempt to make them suitable to incorporate into textile products. In Haryana, most crafts and traditional motifs have not evolved into art forms and have remained in their original use, very ethnic and simple, and yet colourful and vibrant enough to express state's rich heritage and it has some beautiful traditional motifs used in handicrafts and their art work including handloom, woven furniture, artistic pottery, wood carving, etc. For the development of designs thirty four screened traditional motifs from the collected motifs of Haryana were developed using CorelDraw12 software. These motifs were geometrical, floral and foliage, animal and bird, human and religious motifs. And a total twenty designs were developed using CorelDraw12 software for apparel articles. Best two designs were transferred on each two ladies kurta using digital embroidery in selected placement for each design and simulation in selected colour way.

\section{Introduction}

Creative designing is the process where the designer plays with the arrangement of line, form and colour to provide beauty to the end product. Introduction of CAD provide great accuracy in designing and quickly visualize the placement of motifs which facilitating the creations of new designs and improving existing designs with reduced time duration CAD system is more advantageous with respect to speed, pattern creation, editing, repeating, flexibility, variety, colour ways and cost effectiveness (Bogarts, 2014). India is a country with rich traditions, which are reflected through the expression of art and crafts of its various regions. Due to diversified talents, interests and inspiration each state has 
its special identity for its unique motifs and designs. The adaptation of design elements of different Indian crafts can easily be adapted for designing textiles. Today designers and artists pick up motifs from traditional designs and incorporate them in the recent context, thereby developing stunning products. This way it is not just the craftsman but also customer who is benefited (Kumar, 2015). Sethi and Sharma (2011) highlighted that computer in the hands of a designer can prove to be a tool of unlimited creativity with the system working as simple as an artist sketch book. The demonstrated benefits of CAD included increased productivity, reduced product development time, increased creativity to improve conceptual design, high product design capacity, reduced cost of sample and prototype. Naik and Byadgi (2010) stated that in the present scenario of fast life style, designs with assistance of CAD has not only expanded horizon of designing but also can create any number of designs that could be saved in the library to apply as and when required. CAD systems are more advantageous with respect to the speed, pattern creation, editing, repeating, flexibility, variety, colour ways and cost effective.

\section{Materials and Methods}

The methodology i.e. the methods and procedures undertaken for the development of data with the objectives of development of motifs for ladies kurta using digital embroidery may be described by a series of steps described as under:

\section{Collection of motifs}

A total of 102 motifs were screened which were considered suitable for application on apparels and critically analyzed by researcher and advisor, on the basis of their suitability to digital embroidery technique for ladies kurta. These motifs were categorize into five category i.e. geometrical, floral and foliage, animal and bird, human and religious motifs. On the basis of mean scores, ranks were assigned to the motifs of each category of motifs. A total of thirty four motifs, one third top ranked motifs from each category of motifs, were selected. These were again created and refined on computer using Corel Draw and Adobe Photoshop software to get the required intricacy and Plate-1.

\section{Development of Designs}

The selected thirty four motifs were created in CorelDRAW-12 to get the required intricacy and fineness shown in Plate 2. The process of the development of the motifs using CorelDRAW-12 is shown in Figure-1.

\section{Results and Discussion}

A total of 400 motifs were collected and screened one hundred two motifs. Top one third motifs from each five category i.e. 8 from geometrical, 6 from floral and foliage, 8 from animal and bird, 6 from human and 6 from religious motifs were selected.

All selected motifs were developed into contemporary form using CorelDraw software. Amongst thirty four developed motifs may be used for creation of design and top ranked two designs on the bases of expert's choice used for application on ladies kurta using digital embroidery, shown in Plate 3.

From the study it was concluded that the traditional Haryana motifs i.e. geometrical, floral and foliage, animal and bird, human and religious motifs can be created in contemporary form. The traditional Haryana motifs have endless possibilities for combining artistically to create unique designs for application on apparels, home textiles and utility articles. 
These Haryana motifs were successfully adapted by CAD for the application of surface enrichment of designing. The use of CAD has helped in creating new and complex designs using Haryana motifs and reduced the time involved in the entire process of textile designing. The selected design placements were easily transferred on to ladies kurta through digital embroidery in selected colour way.

Fig.1 Creation of Design

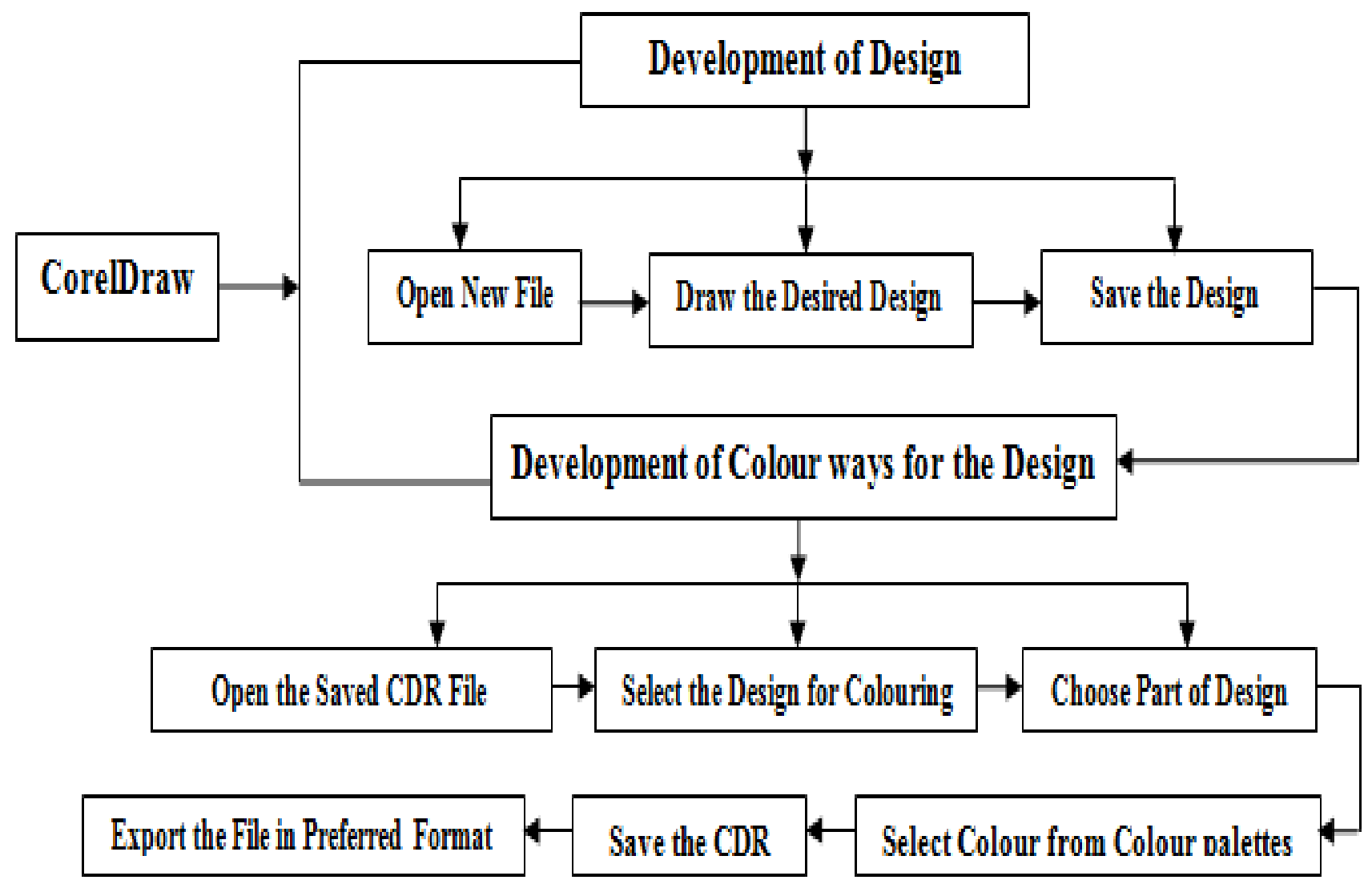


Plate.1 Selected Motifs

\begin{tabular}{|c|c|c|c|c|c|c|c|c|c|}
\hline $\begin{array}{l}\text { Rank } \\
\text { S } \\
\text { (MS) }\end{array}$ & $\begin{array}{l}\text { Geometrica } \\
\text { I Motifs } \\
\text { (Motif } \\
\text { Codes) }\end{array}$ & $\begin{array}{c}\text { Rank } \\
\text { S } \\
(\mathrm{MS})\end{array}$ & $\begin{array}{l}\text { Floral and } \\
\text { Foliage } \\
\text { Motifs } \\
\text { (Motif } \\
\text { Codes) }\end{array}$ & $\begin{array}{c}\text { Ranks } \\
\text { (MS) }\end{array}$ & $\begin{array}{c}\text { Animal and } \\
\text { Bird Motifs } \\
\text { (Motif } \\
\text { Codes) }\end{array}$ & $\begin{array}{c}\text { Ranks } \\
\text { (MS) }\end{array}$ & $\begin{array}{l}\text { Human } \\
\text { Motifs } \\
\text { (Motif } \\
\text { Codes) }\end{array}$ & $\begin{array}{c}\text { Rank } \\
\text { S } \\
(\mathbf{M S})\end{array}$ & $\begin{array}{l}\text { Geometrica } \\
\text { I Motifs } \\
\text { (Motif } \\
\text { Codes) }\end{array}$ \\
\hline $\begin{array}{c}\text { I } \\
(22.0 \\
\mathbf{0})\end{array}$ & $\left(\mathrm{G}_{2}\right)$ & $\begin{array}{c}\text { I } \\
(15.7 \\
0)\end{array}$ & $\begin{array}{c}\% / F^{\circ} \\
\left(F_{9}\right)\end{array}$ & $\begin{array}{c}\text { I } \\
(21.87)\end{array}$ & $\left(A_{15}\right)$ & $\begin{array}{c}\text { I } \\
(14.47)\end{array}$ & $\left(\mathrm{H}_{6}\right)$ & $\begin{array}{c}\text { I } \\
(16.0 \\
0)\end{array}$ & (e) \\
\hline $\begin{array}{c}\text { II } \\
(18.6 \\
\text { 0) }\end{array}$ & $\frac{\left(\mathrm{G}_{19}\right)}{(-1)}$ & $\begin{array}{c}\text { II } \\
(15.5 \\
3)\end{array}$ & $\left(\mathrm{F}_{5}\right)$ & $\begin{array}{c}\text { II } \\
(18.70)\end{array}$ & $\left(\mathrm{A}_{9}\right)$ & $\begin{array}{c}\text { II } \\
(13.73)\end{array}$ & (I & $\begin{array}{c}\text { II } \\
(14.7 \\
0)\end{array}$ & $\left(\mathbf{R}_{1}\right)$ \\
\hline $\begin{array}{l}\text { III } \\
(18.1 \\
3)\end{array}$ & $\left(\mathrm{G}_{1}\right.$ & $\begin{array}{l}\text { III } \\
(15.1 \\
3)\end{array}$ & or & $\begin{array}{c}\text { III } \\
(18.33)\end{array}$ & & $\begin{array}{c}\text { III } \\
(13.60)\end{array}$ & $\begin{array}{l}\frac{10 \text { L }}{000000} \\
\left(\mathrm{H}_{2}\right)\end{array}$ & $\begin{array}{c}\text { III } \\
(14.4 \\
7)\end{array}$ & $\left(R_{12}\right)$ \\
\hline $\begin{array}{c}\text { IV } \\
(17.5 \\
\text { 0) }\end{array}$ & $\left(\mathrm{G}_{5}\right)$ & $\begin{array}{l}\text { IV } \\
(13.1 \\
3)\end{array}$ & (F) & $\begin{array}{c}\text { IV } \\
(17.97)\end{array}$ & $\left(\mathrm{A}_{12}\right)$ & $\begin{array}{c}\text { IV } \\
(13.07)\end{array}$ & X) & $\begin{array}{l}\text { IV } \\
(14.4 \\
3)\end{array}$ & $\underbrace{0}_{0})_{0}^{0} 0$ \\
\hline $\begin{array}{c}V \\
(16.7 \\
7)\end{array}$ & $\left(\mathrm{G}_{20}\right)$ & $\begin{array}{c}\mathrm{V} \\
(13.0 \\
0)\end{array}$ & 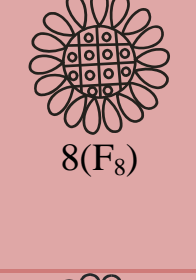 & $\begin{array}{c}\mathrm{V} \\
(17.47)\end{array}$ & $\begin{array}{r}\left.\mathrm{A}_{21}\right) \\
\left(\mathrm{A}_{21}\right)\end{array}$ & $\begin{array}{c}\mathrm{V} \\
(12.90)\end{array}$ & $\begin{array}{c}\left.{ }^{8} \mathrm{H}_{9}\right) \\
\end{array}$ & $\begin{array}{c}\mathrm{V} \\
(13.9 \\
3)\end{array}$ & $\left(\mathbf{R}_{3}\right)^{k}$ \\
\hline $\begin{array}{c}\text { VI } \\
(15.8 \\
7)\end{array}$ & $\begin{array}{c}\left.\mathrm{I}_{7}\right) \\
\left(\mathrm{G}_{7}\right)\end{array}$ & $\begin{array}{c}\text { VI } \\
(12.5 \\
3)\end{array}$ & $\begin{array}{c}0.989 \\
\left(F_{12}\right)\end{array}$ & $\begin{array}{c}\text { VI } \\
(16.47)\end{array}$ & $\left(\mathrm{A}_{4}\right)$ & $\begin{array}{c}\text { VI } \\
(12.17)\end{array}$ & $\begin{array}{l}\left(\mathrm{H}_{3}\right) \\
\text { (6) }\end{array}$ & $\begin{array}{c}\text { VI } \\
(13.9 \\
0)\end{array}$ & $\begin{array}{l}\left(\begin{array}{c}3 \\
3\end{array}\right) \\
\left(\mathbf{R}_{11}\right)\end{array}$ \\
\hline $\begin{array}{c}\text { VII } \\
(14.6 \\
3)\end{array}$ & 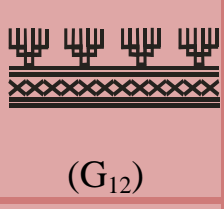 & & & $\begin{array}{c}\text { VII } \\
(16.33)\end{array}$ & $\left(\mathrm{A}_{20}\right)$ & & & & \\
\hline $\begin{array}{c}\text { VIII } \\
(14.3 \\
7)\end{array}$ & f. f. f. & & & $\begin{array}{c}\text { VIII } \\
(15.73)\end{array}$ & 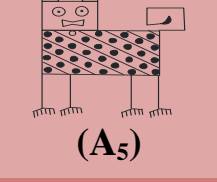 & & & & \\
\hline
\end{tabular}


Plate.2 Developed Designs

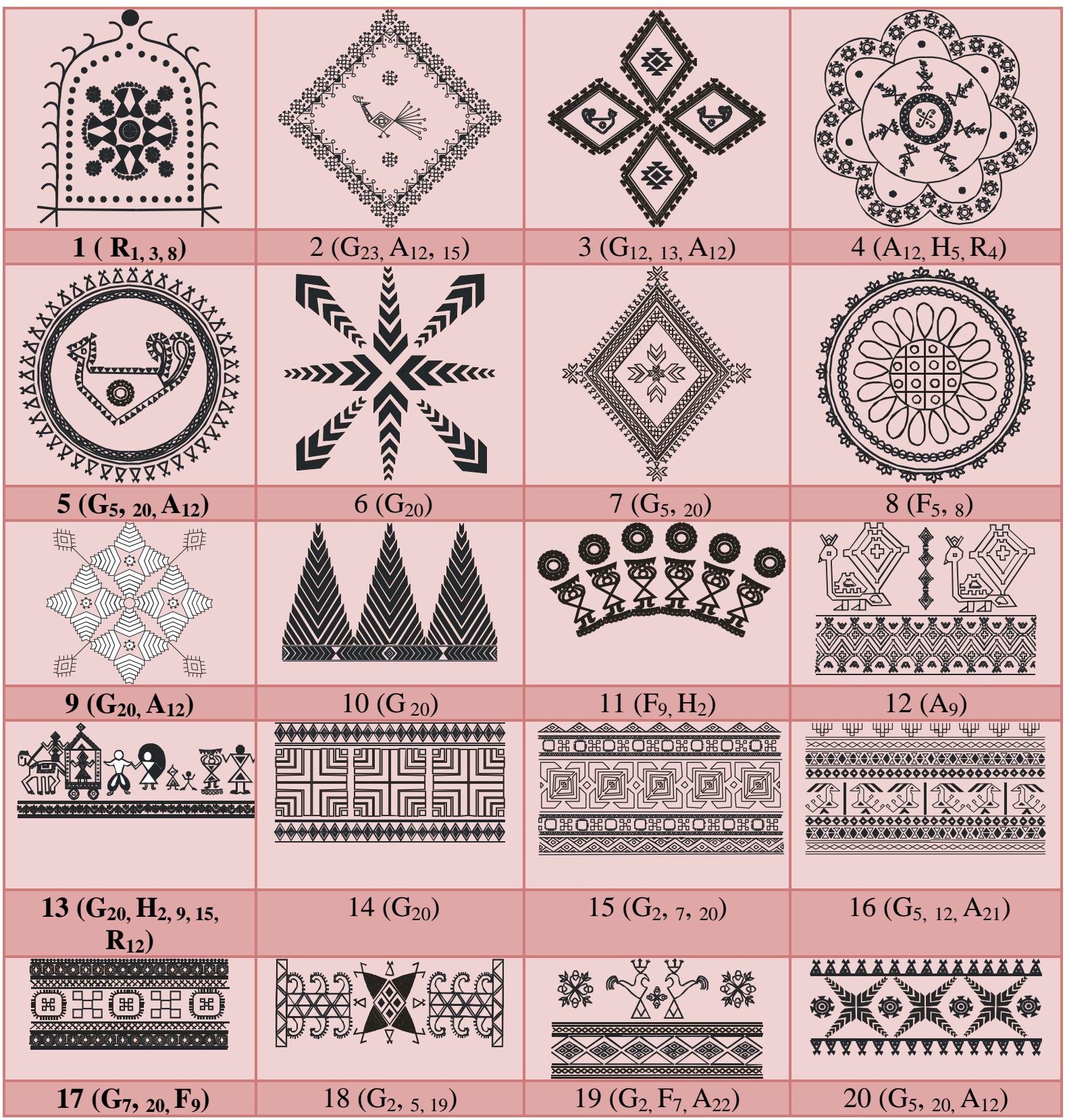


Plate.3 Selected Designs for Ladies Kurta

\begin{tabular}{|c|c|c|c|}
\hline Apparels & Ranks & Design No. & Selected Designs \\
\hline Ladies Kurta & I & 13 & \\
\cline { 2 - 4 } & II & 10 & \\
\hline
\end{tabular}

\section{References}

Bogart W. 2014. New development in CAD for the fashion designers. Retrieved from www.designer.com on August 25, 2014.

Kumar R. 2015. Designer's creation. Retrieved from www.retukumar.com on April 13, 2015.

Sethi R C and Sharma R B. 2011. CAD in the hands of the designer. Asian $\mathrm{J}$ Home Sci, 6(2): 292-294.
Naik S D and Byadgi S A. 2010. Automation of hand embroidery motifs into self woven designs. Karnataka $J$ Agricultural Sci, 23 (4): 668-672.

Latif S, Khan R, Durani F and Wahab Z. 2012. Textile designs based on Kashmiri wood work motifs identified and collected from the traditional buildings located at Muzaffarabad and Neelum Valley, Azad Kashmir. Greener J Art and Humanities, 2 (1):17.

\section{How to cite this article:}

Sunita, Neelam M. Rose and Saroj S. Jeet Singh. 2021. Development of Innovative Designs for Ladies Kurta using Traditional Haryana Motifs. Int.J.Curr.Microbiol.App.Sci. 10(04): 218-223. doi: https://doi.org/10.20546/ijcmas.2021.1004.021 